\title{
The prevalence of fibromyalgia in Brazil - a population-based study with secondary data of the study on chronic pain prevalence in Brazil
}

\author{
A prevalência da fibromialgia no Brasil - estudo de base populacional com dados secundários \\ da pesquisa de prevalência de dor crônica brasileira
}

Juliana Barcellos de Souza1 ${ }^{1}$ Dirce Maria Navas Perissinotti ${ }^{2}$

DOI 10.5935/2595-0118.20180065

\section{ABSTRACT}

BACKGROUND AND OBJECTIVES: The prevalence of the fibromyalgia syndrome has been estimated in some Brazilian cities and regions, and previous population-based studies investigating this prevalence, as well as the profile of medical consultations are unknown.

METHODS: This study used the database constructed by a previous study of authors to identify the prevalence of chronic pain in Brazil. The cases that reported pain for more than 6 months and with a diagnosis of fibromyalgia were selected. The studied descriptive variables were age, intensity and frequency of pain, pain interference in self-care, walking, working, social life, sexual life, sleep quality, if pain causes sadness or depression or influences the emotional aspects. The total sample was evaluated by rheumatologists and pain-expert doctors.

RESULTS: Thirteen cases from the initial database were selected since they reported the diagnosis of the prevalence of the fibromyalgia syndrome representing $2 \%$ of the initial study population, average age 35.8 years (9.8). The predominance of the fibromyalgia syndrome was in females $(n=11)$. Pain intensity was 7.3 (2.4), the frequency and duration of pain were constant in the majority of the sample $(n=9)$. Most of the cases report a serious pain interference with sleep $(n=8)$, many said that pain interferes with the work $(n=5)$, irritability (5) and finally, some report that pain has a moderate interference in self-care $(n=5)$, walking $(n=6)$, social life $(n=6)$, sexual life $(n=5)$ and causes moderate sadness or depression $(n=5)$.

CONCLUSION: The prevalence of the fibromyalgia syndrome was estimated in $2 \%$ of the Brazilian population, based on secondary data of a study on chronic pain prevalence in Brazil. The data was collected in 2015-2016. The most reported complaints were intense and daily pain that interferes with sleep.

1. Universidade Federal de Santa Catarina, Hospital Universitário, Florianópolis, SC, Brasil. 2. Universidade de São Paulo, Faculdade de Medicina, Disciplina de Anestesiologia, Equipe de Controle da Dor, São Paulo, SP, Brasil.

Submitted on August 31, 2018.

Accepted for publication on September 24, 2018.

Conflict of interests: none - Sponsoring sources: none.

Correspondence:

Juliana Barcellos de Souza.

Serv. Natalícia Pereira, 129, casa 1

88030-361 Florianópolis, SC, Brasil.

E-mail: juliana@educaador.com

(C) Sociedade Brasileira para o Estudo da Dor
Keywords: Constant pain, Fibromyalgia syndrome, Intense pain, Prevalence, Sleep.

\section{RESUMO}

JUSTIFICATIVA E OBJETIVOS: A prevalência de síndrome de fibromialgia já foi estimada em cidades e regióes pontuais do Brasil, desconhece-se estudos anteriores de base populacional que investiguem a prevalência, assim como o perfil de consultas médicas. MÉTODOS: Este estudo utilizou dados secundários ao banco de dados construído por uma pesquisa prévia para identificar a prevalência de dor crônica no Brasil. Foram selecionados os casos que responderam sentir dores há mais de 6 meses e com diagnóstico de fibromialgia. As variáveis analisadas de forma descritiva foram: idade, intensidade e frequência da dor, interferência da dor no autocuidado, na caminhada, no trabalho, na vida social, na vida sexual, na qualidade do sono, se dor causa tristeza ou deprime ou influencia os aspectos emocionais. A totalidade da amostra foi avaliada tanto por reumatologistas como por especialistas em dor. RESULTADOS: Treze casos do banco de dados inicial foram selecionados por afirmarem ter recebido o diagnóstico de síndrome de fibromialgia, representando $2 \%$ da população do estudo inicial, idade média de 35,8 anos $(9,8)$. A predominância de síndrome de fibromialgia foi no gênero feminino $(n=11)$. Intensidade de dor de $7,3(2,4)$, a frequência e duração da dor é constante na maioria da amostra $(n=9)$. A maioria dos casos relata muita interferência da dor no sono $(n=8)$, alguns classificam que a dor interfere muito no trabalho $(n=5)$, irritabilidade (5) e finalmente, alguns relatam que a dor interfere moderadamente no autocuidado $(n=5)$, caminhada $(n=6)$, vida social $(n=6)$, vida sexual $(n=5)$ e causa moderamente tristeza ou deprime $(n=5)$.

CONCLUSÃO: A prevalência da síndrome de fibromialgia foi estimada em $2 \%$ da população brasileira pelo viés de dados secundários de um estudo de prevalência de dor crônica no Brasil cujo dados foram coletados em 2015-2016. As queixas relatadas pela maioria dos casos foram de dor intensa e diária e com interferência da dor no sono.

Descritores: Dor constante, Dor intensa, Prevalência, Síndrome de fibromialgia, Sono.

\section{INTRODUCTION}

Chronic pain is recognized as a public health problem. The high prevalence and indicators of an increase in the incidence of chronic pain, such as fibromyalgia syndrome (FMS $)^{1}$, generate 
questions about diagnosis, therapeutic approach, and intensity of symptoms reported by patients ${ }^{2}$. The economic cost and the social wasting added to the needs of the people suffering from chronic generalized painful condition, such as FMS, has a negative impact in several countries around the world, as well as in Brazil. It is estimated that the physical and emotional incapacity generated by pain is among the 10 causes of greater socioeconomic impact in developed and developing countries ${ }^{3}$.

The prevalence of FMS is estimated at around 2.5\% of the population $^{4}$, although recent studies have shown an increase in this prevalence for $5 \%$ of women in the United States 5 and $4.7 \%$ of the population of some European countries ${ }^{6}$. FMS is not the most prevalent chronic pain worldwide or in Brazil. However, it is the focus of much research and study because of the complex clinical picture and because it is costly to the health system. It is estimated that a patient with FMS generates direct costs 2 to 3 times more than other patients with chronic pain in Canada ${ }^{7}$ and the United States ${ }^{8}$, respectively. Direct health cost involves the number of medical consultations, laboratory examinations, and imaging; drugs and other treatments. Indirect costs are also representative of the socioeconomic burden and are measured by days of work withdrawal, loss of productivity, disability pensions, among others.

In Brazil, in addition to the variability in the clinical manifestation of FMS, great geographic distances, different historical heritages, and distinct social realities between the states and regions of the country are faced'. In addition, social inequality has repercussions on access to health, whether regarding diagnosis or treatment.

Investments for the elaboration of public policies are based on the population needs identified by epidemiological studies. And, on the other hand, the implementation of health programs is planned according to the characteristics of the population suffering from FMS. Basic or experimental research is also guided by these characteristics of population studies; either for the elaboration or validation of pharmacological treatments, exercise protocols, application of techniques and specific methods of different health areas. The complexity of the studies with the population suffering from FMS is due to both variability of its clinical manifestation (intense diffuse pain, deficits in mechanisms of pain modulation, mood and sleep disorders, digestive alterations, cognitive symptoms, fatigue among others) and the difficulty of access to the diagnosis and the variability of the population's needs. Brazilian studies estimate the prevalence of FMS around 2.5\% $\%^{4}$. Previous, population-based studies that investigate the prevalence, and which medical specialties patients refer to, and which symptoms of major complaints, are unknown. In a previous study, it was observed the prevalence of chronic pain in the Brazilian population ${ }^{10}$.

This study aimed to describe the profile of the Brazilian population with FMS.

\section{METHODS}

Secondary data from a previous study were used to identify the prevalence of chronic pain in Brazil ${ }^{10}$. The sample calculation for the chronic pain prevalence study database used the following parameters: adult population (18 years old or more) estimated at 143 million, the prevalence of the outcome (20\%), sampling error of 4 percentage points and interval of $95 \%$ confidence interval $(\mathrm{n}=385)$. The sample size obtained was multiplied by two because of the study design, plus 30\% predicted losses. The sample was estimated at 1000 people, extended to 1011 and distributed by the demographic density of each state of the federation and the Federal District. The sample was randomized from a private database with more than one million cell phone numbers. According to the Brazilian Institute of Geography and Statistics, 73\% of the Brazilian population has a cell phone number ${ }^{10}$. The database was constructed from November 2015 to February 2016, by telephone interview, using the questionnaire validated in Portuguese ${ }^{10}$. The secondary data used were the cases that stated chronic pain for more than six months and that they had been diagnosed by one (or more) doctors with the diagnosis of FMS. The independent variables for the description of the epidemiological profile and the use of health services were sociodemographic characteristics (age, gender), characterization of pain by frequency, intensity, acute pain crises, pain localization, pain interference in selfcare, walking, work, social life, sexual life, sleep quality, if the pain causes sadness or depresses or influences the emotional aspects. Which doctors consulted patients with pain were also evaluated.

\section{Statistical analysis}

The data analysis was descriptive, mean and standard deviation for the continuous variables, number of cases and percentage according to gender for the discrete and categorical variables. The data were analyzed in SPSS version 20.0 for Windows.

\section{RESULTS}

In the database of the original study, 723 participants were interviewed of the 1101 phone calls made, 304 responded to have chronic pain, and 13 reported having a diagnosis of FMS. These correspond to $2 \%$ of the total sample, being 2 cases of males and 11 of females, establishing a gender ratio of 1 man to 5.6 women (1:5.6). Sixty-nine percent $(n=9)$ of the participants responded to consult with a rheumatologist, followed by $23 \%$ who see a pain specialist physician. Only one participant reported being accompanied by more than one doctor. Fifteen percent of participants (one female and one male) treated as a strategy for pain management, while 69\% ( $n=9)$ emphasized pharmacological treatment as a strategy. One patient reported not following any treatment, and another responded to perform other strategies (among physical therapy, Pilates, use of orthoses, etc.). Table 1 presents the characteristics of pain and the interference of pain in activities of daily life. Most of the cases reported a great deal of pain interference with sleep $(n=8)$, some classified pain greatly interferes with work $(\mathrm{n}=5)$, irritability (5) and finally some reported that pain moderately interferes with self-care $(n=5)$, walking $(n=6)$, social life $(n=6)$, sexual life $(n=5)$ and causes moderately sadness or depression $(\mathrm{n}=5)$. 
Table 1. Characteristics of cases with fibromyalgia syndrome - Study database with the populational database - Brazil (2015-2016) ${ }^{10}$

\begin{tabular}{|c|c|c|c|}
\hline & Male $(n=2)$ & $\begin{array}{l}\text { Female } \\
(n=11)\end{array}$ & Total \\
\hline Mean age (SD) & $34.5 \pm 10.6$ & $36.1 \pm 10.1$ & $35.8 \pm 9.8$ \\
\hline Intensity of pain (SD) & $7.5 \pm 0.7$ & $7.3 \pm 2.6$ & $7.3 \pm 2.4$ \\
\hline \multicolumn{4}{|c|}{$\begin{array}{l}\text { Pain frequency/weekly (days) } \\
\text { (\% and } \mathrm{n})\end{array}$} \\
\hline Less than a day & $0(0)$ & $0(0)$ & $0(0)$ \\
\hline $1-2$ & $0(0)$ & $18(2)$ & $15(2)$ \\
\hline $3-4$ & $50(1)$ & $9(1)$ & $15(2)$ \\
\hline $5-7$ & $50(1)$ & $72(8)$ & $69 \%(9)$ \\
\hline \multicolumn{4}{|c|}{$\begin{array}{l}\text { Duration of pain crises* }(n-12) \\
(\% \text { and } n)\end{array}$} \\
\hline Brief & $0(0)$ & $0(0)$ & $0(0)$ \\
\hline Few hours & $50(1)$ & $18(2)$ & $23(3)$ \\
\hline One day & $0(0)$ & $0(0)$ & $0(0)$ \\
\hline Constant & $50(1)$ & $72(8)$ & $69(9)$ \\
\hline \multicolumn{4}{|l|}{$\begin{array}{l}\text { Interference of pain in } \\
\text { self-care }(\% \text { and } n)\end{array}$} \\
\hline None & $50(1)$ & $9(1)$ & $15(2)$ \\
\hline Little & $0(0)$ & $27(3)$ & $23(3)$ \\
\hline Moderate & $50(1)$ & $36(4)$ & $38(5)$ \\
\hline Much & $0(0)$ & $18(2)$ & $15(2)$ \\
\hline \multicolumn{4}{|c|}{$\begin{array}{l}\text { Interference of pain with } \\
\text { walking }^{\star}(\% \text { and } n)\end{array}$} \\
\hline None & $0(0)$ & $9(1)$ & $7(1)$ \\
\hline Little & $0(0)$ & $0(0)$ & $0(0)$ \\
\hline Moderate & $50(1)$ & $45(5)$ & $46(6)$ \\
\hline Much & $0(0)$ & 27 (3) & $23(3)$ \\
\hline \multicolumn{4}{|c|}{$\begin{array}{l}\text { Interference of pain with } \\
\text { work (\% and } n)\end{array}$} \\
\hline None & $0(0)$ & $0(0)$ & $0(0)$ \\
\hline Little & $0(0)$ & $9(1)$ & $7(1)$ \\
\hline Moderate & $50(1)$ & $27(3)$ & $31(4)$ \\
\hline Much & $0(0)$ & $45(5)$ & $38(5)$ \\
\hline \multicolumn{4}{|c|}{$\begin{array}{l}\text { Interference of pain with } \\
\text { social life }(\% \text { and } n)\end{array}$} \\
\hline None & $0(0)$ & $0(0)$ & $0(0)$ \\
\hline Little & $50(1)$ & $18(2)$ & $23(3)$ \\
\hline Moderate & $0(0)$ & $45(5)$ & $38(5)$ \\
\hline Much & $0(0)$ & $18(2)$ & $15(2)$ \\
\hline \multicolumn{4}{|l|}{$\begin{array}{l}\text { Pain causes irritability } \\
(\% \text { and } n)\end{array}$} \\
\hline No & $50(1)$ & $9(1)$ & $15(2)$ \\
\hline Little & $0(0)$ & $0(0)$ & $0(0)$ \\
\hline Moderate & $0(0)$ & $36(4)$ & $31(4)$ \\
\hline Much & $0(0)$ & $45(5)$ & $38(5)$ \\
\hline \multicolumn{4}{|c|}{$\begin{array}{l}\text { Pain causes sadness or } \\
\text { depression ( } \% \text { and } n)\end{array}$} \\
\hline No & $50(1)$ & $9(1)$ & $15(2)$ \\
\hline Little & $0(0)$ & $9(1)$ & $7(1)^{\prime}$ \\
\hline Moderate & $0(0)$ & $45(5)$ & $38(5)$ \\
\hline Much & $0(0)$ & 27 (3) & $23(3)$ \\
\hline \multicolumn{4}{|l|}{$\begin{array}{l}\text { Pain affects sexual life } \\
(\% \text { and } n)\end{array}$} \\
\hline No & $50(1)$ & $18(2)$ & $23(3)$ \\
\hline Little & $50(1)$ & $9(1)$ & $15(2)$ \\
\hline Moderate & $0(0)$ & $45(5)$ & $38(5)$ \\
\hline Much & $0(0)$ & $18(2)$ & $15(2)$ \\
\hline \multicolumn{4}{|c|}{ Pain disrupts sleep (\% and $n)$} \\
\hline No & $0(0)$ & $0(0)$ & $0(0)$ \\
\hline Little & $0(0)$ & $27(3)$ & $23(3)$ \\
\hline Moderate & $0(0)$ & $9(1)$ & $7(1)$ \\
\hline Much & $50(1)$ & $54(6)$ & $62(8)$ \\
\hline
\end{tabular}

\section{DISCUSSION}

The prevalence of FMS in the Brazilian population was $2 \%$ with a proportion of $1 \mathrm{man}$ for every 5.5 women. These results are equivalent to previous studies performed in specific regions of Brazil, such as São Paulo ${ }^{4}$. However, when compared to more recent studies, they present a lower prevalence value than the United States and European countries ${ }^{6,7}$. It is estimated that updating the FMS classification criteria, as well as the increased acceptance of the diagnosis, may directly influence the increase in the indicated values of prevalence. FMS has its classification criteria established by American College of Rheumatology ${ }^{11}$ and these are widely discussed in Brazil in groups of rheumatologists ${ }^{12}$ and groups of studies of pain ${ }^{13}$. Most of the cases in this study reported consulting - mainly - rheumatologists, followed by pain specialists. In this case, the information bias and the social and geographical condition for access to the health service and diagnosis are also applicable. In Brazil, access to health services is sometimes scarce in some regions of the country, as well as the outdating of some professionals in regions away from large centers, since the FMS diagnostic criteria are updated ${ }^{11,14,15}$ and generate many discussions among clinicians and researchers ${ }^{12}$. As well as the limitation for access to diagnosis, the treatment plan and access to medication also make the prognosis of this population difficult. In order to optimize the planning of new treatment practices for this population, it was found that constant pain, high intensity, and sleep disorders are the main complaints of most of the cases investigated. The presence of constant pain is redundant to the diagnostic criteria. Although the vast majority of cases report consulting doctors, the data contradict expectations of pain at lower intensities or less frequent when treated. It is recognized that the success of the treatment depends on several factors. In addition to access to the specialist doctor, there are: (a) access to the drug, (b) access to the physical therapist, psychologist and other health professionals, (c) management of pain by unimodal versus multimodal treatment, (d) communication between patient, doctor and other health professionals who accompany the patient with FMS, (e) patient's financial resources to access drugs, and consultations with the professionals who attend him/her, (f) availability of drugs and health professionals specialized in the treatment of pain, $(\mathrm{g})$ compliance with pharmacological treatment, therapeutic process and rehabilitation ${ }^{16-19}$. Sleep disorders are another recurring symptom among those interviewed in this study, most of whom describe that pain greatly interferes with sleep quality. Sleep disorders are directly related to the patients' sensitivity to pain ${ }^{20}$, whether due to disturbances in the neuroendocrine metabolism provided at each stage of the sleep cycle or to sleep disruptions caused by the presence of body pain, or by emotional and cognitive symptoms that make it difficult to initiate sleep. For the treatment of FMS, the guidelines ${ }^{18,19}$ recommend changing habits (sleep hygiene, regular practice of physical exercise, breathing and relaxation techniques), sleep-inducing drugs, muscle relaxant, among others. Pain and sleep should follow a multidisciplinary approach, from the evaluation of sleep quality (e.g., polysomnography, validated questionnaires, patient speech, breathing, apnea, snoring), the sleeping environment (e.g., lightness, noise, mattress). The practice of regular and guided physical exercise is included in the guidelines for treatment of FMS both 
for its effect on sleep, as well as pain and $\operatorname{mood}^{17,21}$. The aspects of the relational and affective sphere to the interference of pain and aspects of work and social life tend to present greater impact for the female population in this study. Pain causes feelings of depression causes irritation and affects the sexual life, which seems compatible with what studies ${ }^{17}$ have been recommending, that is, that more there is interference of the pain in different aspects of the life more accentuated will be the complaints related to mentioned areas.

Social participation is a variable that gains prominence in research, especially after the publication of the International Classification of Functioning and Disability in 2001 by the World Health Organization $^{22}$. Qualitative studies and multi or interdisciplinary treatment programs support the negative impact of pain on social participation in the population with $\mathrm{FMS}^{17,23}$. Social participation is considered to be the possibility of organizing parties, receiving friends or family, going out at night to meet people or going to the theater/cinema/leisure, practicing leisure activities, concentrating on work and other activities, developing activities that require physical strength or logical reasoning, to be able to balance domestic, work and leisure activities among others ${ }^{24}$. Although in the results of this study there is no tendency to compromise social and labor participation, it is considered necessary to evaluate each case to adjust the treatment plan to the patient.

The interference of pain in sexual life also presents a similar distribution among the categories evaluated. However, previous studies $^{25,26}$ performed mainly with the female population show an impact of FM with sexual activity when compared to an equivalent age/gender population. In addition to diffuse pain, sleep disorders, low level of physical activity, fatigue, depression, and anxiety would also be related to sexual dysfunction in people with $\mathrm{FMS}^{25}$. It is estimated that more than three-quarters of women with FMS have some sexual problem, where depression, anxiety, and sensitivity are the symptoms of increased association with impairment in sexual activity. Physical activity would have a protective behavior to the risk of pain interference in sexual activity ${ }^{27}$.

Management of FMS symptoms goes beyond pain. As previously described, FMS treatment guidelines expand treatments to the goal of reducing pain. Within this multifactorial context,

Brazilian researchers have developed an application (ProFibro) for health promotion, helping patients to manage self-care. In the results of this study, self-care presents a variation between the categories. However this variable remains a challenge in addition to the patients' treatment. It is important to emphasize the need for aids (technological or not) to facilitate the promotion of self-care, such as: sleep monitoring, exercise programs, mood monitoring, among others, such as the gratitude practice proposed by the ProFibro application ${ }^{28}$.

\section{CONCLUSION}

The prevalence of fibromyalgia syndrome was estimated in $2 \%$ of the Brazilian population, through data secondary to a study of chronic pain prevalence.

\section{REFERENCES}

1. Marques AP, Santo AS, Berssaneti AA, Matsutani LA, Yuan SL. Prevalence of fibromyalgia: literature review update. Rev Bras Reumatol. 2017;57(4):356-63. English, Portuguese.

2. Avila LA, de Araujo Filho GM, Guimarães EF, Gonçalves LC, Paschoalin PN, Aleixo FB [Characterization of the pain, Sleep and alexithymia patterns of patients with fibromyalgia treated in a Brazilian tertiary center. Rev Bras Reumatol. 2014;54(5):409-13. Portuguese.

3. Institute for Health Metrics and Evaluation. The Global Burden of Disease: Generating Evidence, Guiding Policy. Seattle, WA: IHME, 2013. www.healthmetricsandevaluation. org (Acessed in 11/06/2018)

4. Senna ER, De Barros AL, Silva EO, Costa IF, Pereira LV, Ciconelli RM, et al. Prevalence of rheumatic diseases in Brazil: a study using the COPCORD approach. J Rheumatol. 2004;31(3):594-7.

5. Lawrence RC, Felson DT, Helmick CG, Arnold LM, Choi H, Deyo RA, et al. Estimates of the prevalence of arthritis and other rheumatic conditions in the United States. Part II. Arthritis Rheum. 2008;58(1):26-35.

6. Branco JC, Bannwarth B, Failde I, Abello Carbonell J, Blotman F, Spaeth M, et al. Prevalence of fibromyalgia: a survey in five European countries. Semin Arthritis Rheum. 2010;39(6):448-53.

7. White KP, Speechley M, Harth M, Ostbye T. The London Fibromyalgia Epidemiology Study: direct health care costs of fibromyalgia syndrome in London, Canada. J Rheumatol. 1999;26(4):885-9.

8. Berger A, Dukes E, Martin S, Edelsberg J, Oster G. Characteristics and healthcare costs of patients with fibromyalgia syndrome. Int J Clin Pract. 2007;61(9):1498-508.

9. Albuquerque MV, Viana AL, Lima LD, Ferreira MP, Fusaro ER, Iozzi FL. Desigualdades regionais na saúde: mudanças observadas no Brasil de 2000 a 2016. Ciênc Saúde Coletiva, 2017;22(4):1055-64.

10. de Souza JB, Grossmann E, Perissinotti DMN, de Oliveira Junior JO, da Fonseca PRB, Posso IP. Prevalence of chronic pain, treatments, perception, and interference on life activities: Brazilian population-based survey. Pain Res Manag. 2017;2017:4643830.

11. Wolfe F, Clauw DJ, Fitzcharles MA, Goldenberg DL, Katz RS, Mease P, et al. The American College of Rheumatology preliminary diagnostic criteria for fibromyalgia and measurement of symptom severity. Arthritis Care Res. 2010;62(5):600-10.

12. Heymann RE, Paiva ES, Martinez JE, Helfenstein M Jr, Rezende MC, Provenza JR, et al. New guidelines for the diagnosis of fibromyalgia. Rev Bras Reumatol. 2017;57(Suppl 2):S467-76.

13. Poluha RP, Grossmann E. Does pregabalin improve sleep disorders in fibromyalgia? Br J Pain. 2018;1(2):163-6.

14. Wolfe F, Smythe HA, Yunus MB, Bennett RM, Bombardier C, Goldenberg DL, et al. The American College of Rheumatology 1990 Criteria for the Classification of Fibromyalgia. Report of the Multicenter Criteria Committee. Arthritis Rheum. 1990;33(3):160-72.

15. Wolfe F, Clauw DJ, Fitzcharles MA, Goldenberg DL, Häuser W, Katz RS, et al. Fibromyalgia criteria and severity scales for clinical and epidemiological studies: a modification of the ACR Preliminary Diagnostic Criteria for Fibromyalgia. J Rheumatol. 2011;38(6):1113-22.

16. Charest J, Boucher J, Duhaime S, Nguyen D-N, Chaize E, Barcellos de Souza J. . Prescription de tâches personnalisées en intervention stratégique pour la douleur chronique. Revue québécoise de psychologie,2015;36:233-50

17. Souza JB, Bourgault P, Charest J, Marchand S. Programa de promoção da saúde em pacientes com fibromialgia - avaliaçăo qualitativa e quantitativa. Revista Dor (São Paulo), 2009; 10:98-105

18. Macfarlane GJ, Kronisch C, Dean LE, Atzeni F, Häuser W, Fluß E, et al. EULAR revised recommendations for the management of fibromyalgia. Ann Rheum Dis. 2017;76(2):318-28.

19. Fitzcharles, MA, Ste-Marie PA, Goldenberg DL, Pereira JX, Abbey S, Choinière M, et al. The National Fibromyalgia Guideline Advisory Panel 2012 Canadian Guidelines for the diagnosis and management of fibromyalgia syndrome: Executive summary. Pain Res Manag, 2013;18(3):119-26.

20. Moldofsky $\mathrm{H}$. The significance, assessment, and management of nonrestorative sleep in fibromyalgia syndrome. CNS Spectr. 2008;13(3 Suppl 5):22-6.

21. Latorre P, Santos M, Heredia-Jiménez J, Delgado-Fernández M, Soto V, Mańas A, et al. Effect of a 24-week physical training programme (in water and on land) on pain, functional capacity, body composition and quality of life in women with fibromyalgia. Clin Exp Rheumatol. 2013;31(6 Suppl 79):S72-80.

22. [WHO] World Health Organization. International Classification of functioning, disability and health: ICF. World Health Organization; 2001.

23. Russell D, Álvarez Gallardo IC, Wilson I, Hughes CM, Davison GW, Sañudo B, et al. 'Exercise to me is a scary word': perceptions of fatigue, sleep dysfunction, and exercise in people with fibromyalgia syndrome-a focus group study. Rheumatol Int. 2018;38(3):507-15

24. Farin E, Ullrich A, Hauer J. Participation and social functioning in patients with fibromyalgia: development and testing of a new questionnaire. Health Qual Life Outcomes. 2013;11:135.

25. Orellana C, Casado E, Masip M, Galisteo C, Gratacós J, Larrosa M. Sexual dysfunction in fibromyalgia patients. Clin Exp Rheumatol. 2008;26(4):663-6.

26. Rosenbaum TY. Musculoskeletal pain and sexual function in women. J Sex Med. 2010:7(2):645-53

27. Collado-Mateo D, Olivares PR, Adsuar JC, Gusi N. Impact of fibromyalgia on sexual function in women. J Back Musculoskelet Rehabil. 2018(9). [Epub ahead of print].

28. Yuan SLK, Marques AP. Development of ProFibro - a mobile application to promote self-care in patients with fibromyalgia. Physiotherapy. 2018;104(3):311-7. 